\title{
Reproductive and larval cycle of the scallop Argopecten purpuratus (Ostreoida: Pectinidae), during El Niño-La Niña events and normal weather conditions in Antofagasta, Chile
}

\author{
Miguel Avendaño ${ }^{1}$, Marcela Cantillánez ${ }^{1}$, Marcel Le Pennec ${ }^{2} \&$ Gérard Thouzeau $^{3}$ \\ 1 Laboratorio de Cultivo y Manejo de Moluscos, Facultad de Recursos del Mar, Universidad de Antofagasta, Av. \\ Universidad de Chile S/N, Casilla 170 Antofagasta, Chile; mavendano@uantof.cl \\ 2 Laboratoire de biologie de l'Uiversité de la Polynésie Française. \\ 3 UMR CNRS 6539 (LEMAR), IUEM, Technopôle Brest-Iroise, Place N. Copernic, 29280 Plouzané, France.
}

Received 27-VI-2006. Corrected 26-VII-2007. Accepted 14-V-2007.

\begin{abstract}
Seasonality, amplitude, and magnitude of spawning events were determined for Argopecten purpuratus in the La Rinconada marine reserve, Antofagasta, Chile, between December 1995 and January 2004. During the same period, samples of scallop larvae were obtained in vertical plankton hauls recovered within this reserve in an area routinely exposed to circular, gyre-like currents which helped retain the larvae within the bay. The reproduction of this population in normal or cool (e.g. "La Niña", 1998-2000) years occurred throughout the year, with a more active period between September and April, declining in June and August; this contrasted with the warmer "El Niño" oceanographic period of 1997-98 in which reproductive activity was more intense and prolonged throughout the entire year. The reproductive events in this population were mostly synchronous, although one asynchronous period occurred each year following the more intense March to May spawnings. This reproductive activity generated a continuous presence of larvae in the area in which no strict relation could be found between the intensities of spawning and numbers of larvae in the water. Larval presence was, however, generally correlated with active spawning periods. Important increases in larval numbers recorded at the end of 1999 and the beginning of 2003 were correlated with census data showing a higher percentage presence of broodstock over $90 \mathrm{~mm}$ in shell length during these years. An adequate stock of this size class is needed for a successful seed capture program in the reserve (for mass culture). Rev. Biol. Trop. 56 (1): 121-132. Epub 2008 March 31 .
\end{abstract}

Key words: Argopecten purpuratus, reproductive cycle, larval cycle, Antofagasta bay, Chile.

A number of studies carried out under national and international auspices, as identified in the Acknowledgements section, were carried out by us at the La Rinconada sector of Antofagasta Bay, Chile $\left(23^{\circ} 28^{\prime} \mathrm{S}, 70^{\circ} 30^{\prime}\right.$ $\mathrm{W})$, based on longstanding empirical observations that this area was unusually productive of the Chilean scallop Argopecten purpuratus (Lamarck 1819). Our overall objective in these studies was to obtain details on the reproductive biology of this pectinid at this location, and determine the feasibility of artificial capture of its larvae in both basic and applied research efforts. The applied research was directed towards the production of mass quantities of "seed" scallops (small juveniles) which could be used to repopulate fisheries-depleted scallop banks in other Chilean bays as well as that of La Rinconada, and ultimately to help supply growing demands for scallop seed by the developing scallop culture industry in Chile.

Results obtained over the past decade on the population dynamics of $A$. purpuratus confirmed that the La Rinconada sector was one of the most important scallop beds in the country. As such it provided and excellent model for studies of the life cycle of this scallop (Avendaño and Cantillánez 1992, 1997, 
2005). Abundance of the scallop in this bed was estimated to be between 8.6 and $16.8 \times 10^{6}$ individuals, spread over an area of 240 ha, with mean densities varying between one and 12 individuals per $\mathrm{m}^{2}$ at depths between 6 and 29 m (Avendaño and Cantillánez 1996, 1997, 2005). In September 1997, the La Rinconada area was declared a marine reserve, based on its coastal location, abundance and other biological characteristics of A. purpuratus, and the unique hydrodynamics particular to this portion of the bay (Avendaño and Cantillánez 1997, Avendaño et al. 2004). Over the last few years, regular sampling carried out on this scallop population has allowed us to gather definitive data on its reproductive cycle and estimate the abundance and distribution of its larvae in the area. We were also able to study the accumulation of postlarvae on a preferred natural substrate, the red alga Rhodymenia sp., as well as effect mass capture of juvenile scallops (seed) in Japanes-type artificial collectors (Cantillánez 2000, Cantillánez et al. 2001, 2005, Avendaño et al. 2006).

The objective of the present study has been to correlate the dynamics of the reproductive cycle in scallop broodstock in the reserve with its effect on larval presence in this environment from the end of 1995 to the beginning of 2004 . This study required a major field effort closely linked to laboratory support during the entire study period, in which we had to overcome not only the difficulties of working in the sea through the different seasons of the year, but also interference by an illegal (clandestine) scallop fishery in there reserve (Avendaño and Cantillánez 1996, 2005).

\section{MATERIALS AND METHODS}

Study area: the study area was located in the NE sector of Antofagasta Bay about $20 \mathrm{~km}$ north of the City of Antofagasta (23⒉ $28^{\prime} 2$ " $\mathrm{S}$ and $\left.70^{\circ} 30^{\prime} 35^{\prime \prime} \mathrm{W}\right)$. The area is subjected to intermittent coastal upwelling throughout the year, with a frequency of 0.2 to 0.4 cycles per day during its most intense period. The irregular presence of this phenomenon can sometimes interrupt the seasonal oceanographic profile in the area, explaining high daily and interannual variability in sea surface temperature which can change by as much as $\pm 6.5^{\circ} \mathrm{C}$ within a $24 \mathrm{~h}$ period (Guillen 1983, Rodríguez et al. 1991, Marín et al. 1993, Escribano et al. 1995, Cantillánez 2000, Avendaño et al. 2004). Bottom water temperature was measured using data loggers (VEMCO, TR model) installed at a depth of $16 \mathrm{~m}$ that recorded the temperature every six hours during great part of the study period.

Peaks of phytoplankton production can occur in the months of April through July, and from September through January, with the months between November and April being the most important. Chlorophyll "a" values can vary from a minimum of $0.6{\mu \mathrm{gl}^{-1}}^{-1}$ to a maximum of $24.8{\mu \mathrm{gl}^{-1}}^{-1}$ Rodríguez et al. 1991, Cantillánez 2000, Avendaño et al. 2004).

The area of the marine reserve experiences variable-direction current flows, with net transport northward. This flow impinges on the north shore of the bay, where it is directed west resulting in a circular gyre-like movement over the scallop bed, retaining the water mass for periods of hours or days. This characteristic allows interchanges and mixing of "bay water" with adjacent water masses, promoting retention of particulate material (eg. plankton) within an area having a radius of about five $\mathrm{km}$.

The internal portion of the reserve also shows the presence of small internal gyres, varying in intensity and position depending on the season, retaining materials and forming inertial areas where sedimentation of transported material can more easily occur. The high capacity for the retention of particulate materials in water entering the marine reserve due to its comparatively long residence period favors the development of planktonic larvae of invertebrates such as those of $A$. purpuratus (Avendaño et al. 2004).

Reproductive cycle: from December 1995 to January 2004, samples of 30 adult $A$. purpuratus ranging in length between 85 and 
$105 \mathrm{~mm}$ were obtained from 14-17 m depths in the marine reserve. Over the first five years, broodstock individuals were recovered every two weeks during periods of highest reproductive activity, and monthly during months of reduced activity. Monthly samples were taken over the last three years of the study. The gonad index (GI) was determined for all these samples as presented by Mottet (1979).

$$
\mathrm{GI}=(\mathrm{GW} / \mathrm{WSP}) * 100
$$

Where:

$\mathrm{GW}=$ wet weight of the gonad

$\mathrm{WSP}=$ wet weight of the soft parts

The average value of this index was calculated for each scallop sample, and the standard deviation was used to calculate the coefficient of variation following Paulet et al. (1997), in order to detect maturation and spawning events in the scallop population, and if these events were synchronous or asynchronous.

Larval samples: quantitative samples of A. purpuratus larvae were obtained at one station in the marine reserve bi-weekly between December 1995 and January 2004. This station was located in an area in which natural recruitment had been empirically observed (Cantillánez and Avendaño 1994), and which coincided with the area of internal gyres as mentioned above. All samples were obtained by making vertical plankton hauls through the entire water column (16 m depth) with a conical plankton net having $53 \mu \mathrm{m}$ mesh openings. These plankton samples were well mixed and separated in ten subsamples using a plankton splitter. Two subsamples were taken from each original sample for counting and measuring of the scallop larvae present using a stereo microscope with an ocular micrometer (Le Pennec 1978, Salaün 1994). Counts were made of larvae measuring less than $170 \mu \mathrm{m}$ in length, and those of $170 \mu \mathrm{m}$ or above. The smaller larvae were considered immature, and the larger group mature and approaching metamorphosis, based on morphological characteristics of the shell teeth (Avendaño 1993). Total numbers of larvae in the water column were estimated by averaging the values of the two subsamples taken from the plankton splitter, and considering the volume of water filtered by the net at each sampling.

\section{RESULTS}

Gonad Index: the study of the variations in the gonad index of $A$. purpuratus determined between December 1995 and January 2004 suggested gamete release throughout the year (Fig. 1), and lack of prolonged resting periods between spawnings. These results also showed that the maximum average values for the GI between December 1995 and September 2000 did not exceed a value of 20 . Higher values were, however, observed between October 2000 and March 2003.

A highly active reproductive period was noted between September and April of each year, with abrupt declines in the index, followed by rapid recuperation. A significant spawning occurs during October, although the more voluminous spawnings occur in November and December. Periods with lower reproductive activity occur in the fall months (June to August) in which there are only minor variations in the GI.

Some alterations in the above described pattern were induced by the presence of the El Niño Southern Oscillation (ENSO) phenomenon of 1997-98 where after a sustained decline in the GI from January 1997 which reached a minimum in February of that year, there was a partial re-maturation of the population in March, initiating a new intense reproductive period which was unusually prolonged from the winter of 1997 to April 1998. The decline of the ENSO event in May 1998, where the GI reached its lowest value for this population (4) marked the beginning of a new period of minimum reproductive activity.

During the occurrence of the "La Niña" phenomenon (1998-2000), typified by unusually low sea surface temperatures, there were 

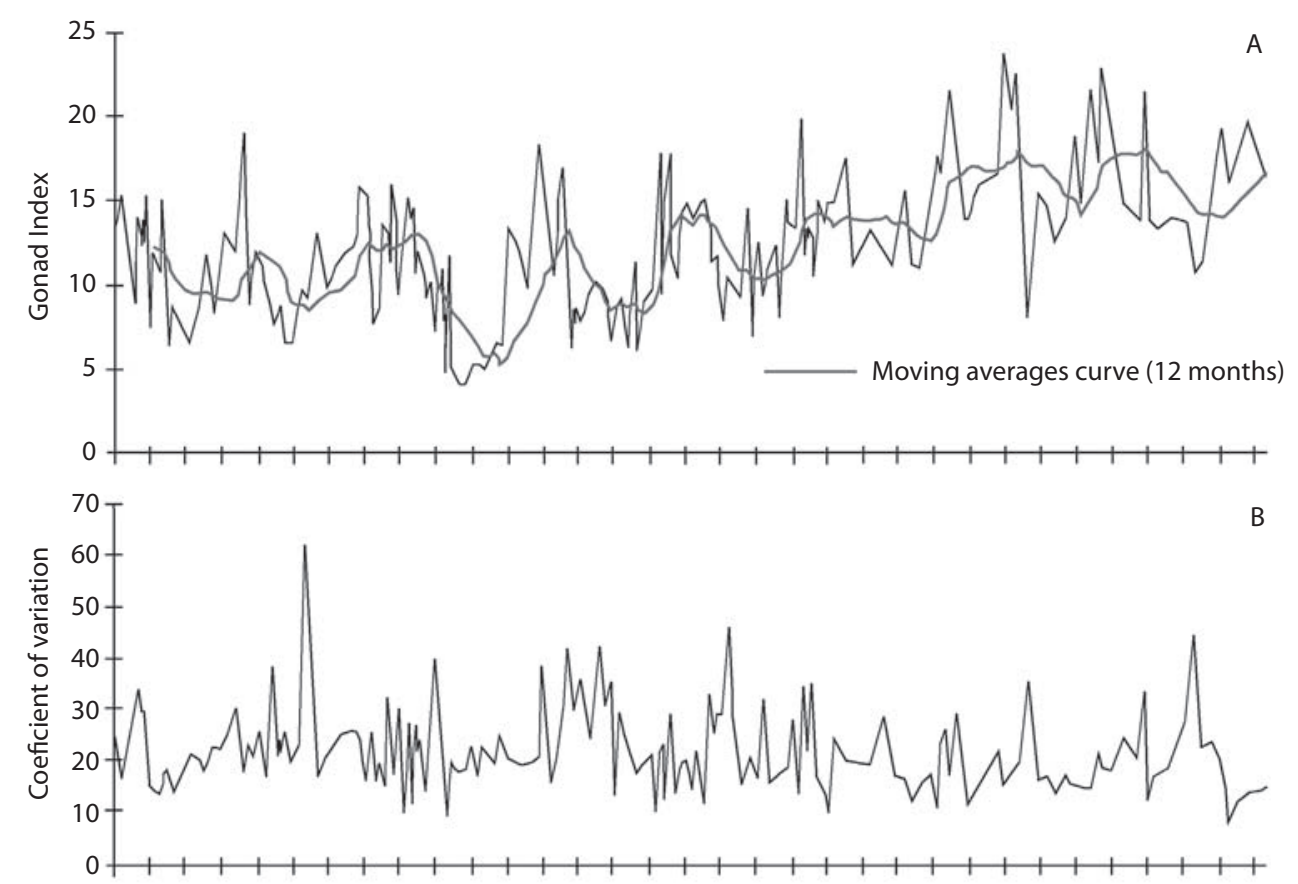

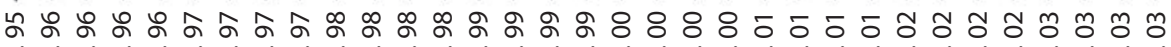

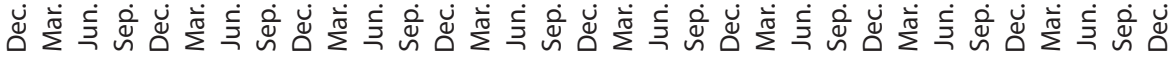

Date

Fig. 1. Variation in gonad index (GI) of the population of A. purpuratus (A), and development of its coefficient of variation (B), between December 1995 and January 2004 in the La Rinconada marine reserve.

no major deviations from the reproductive pattern recorded during "normal" years, with the exception of the observation beginning in January and February of 2000 where the GI did not show pronounced variations until June, when there was a major drop index of 7.5 points at the end of the La Niña period.

\section{Synchrony of the reproductive process:} the average value of the coefficient of variation of the GI was $21.8 \%$, which suggested a high synchrony in the reproductive events occurring in the population studied. Nevertheless, in graphic form we observed strong and rapid seasonal variations in synchrony; in general terms, the greatest period of asynchrony occurred in the fall (March through May), which was followed by rapid synchronization in winter (Fig. 1).
Annual patterns of larval abundance: results obtained from the larval sampling showed an essentially continuous presence of larvae in the water over the La Rinconada scallop bed. Figure 2 shows larval densities found in all the samples. These data show an important increase in larval abundance occurring between December 1999 and April 2003, with larval counts reaching maxima of $21758 \mathrm{~m}^{-3}$ in December 1999; 16100 in April 2000, 34175 in May 2001, 29802 in March 2002, and 23852 in January 2003. Beginning in June 2003 these numbers decreased to the same level of values observed between December 1995 and October 1999 where the maximum abundance recorded was 4840 larvae $\mathrm{m}^{-3}$. These data suggested that there were periods of higher larval abundance beginning in November and December 


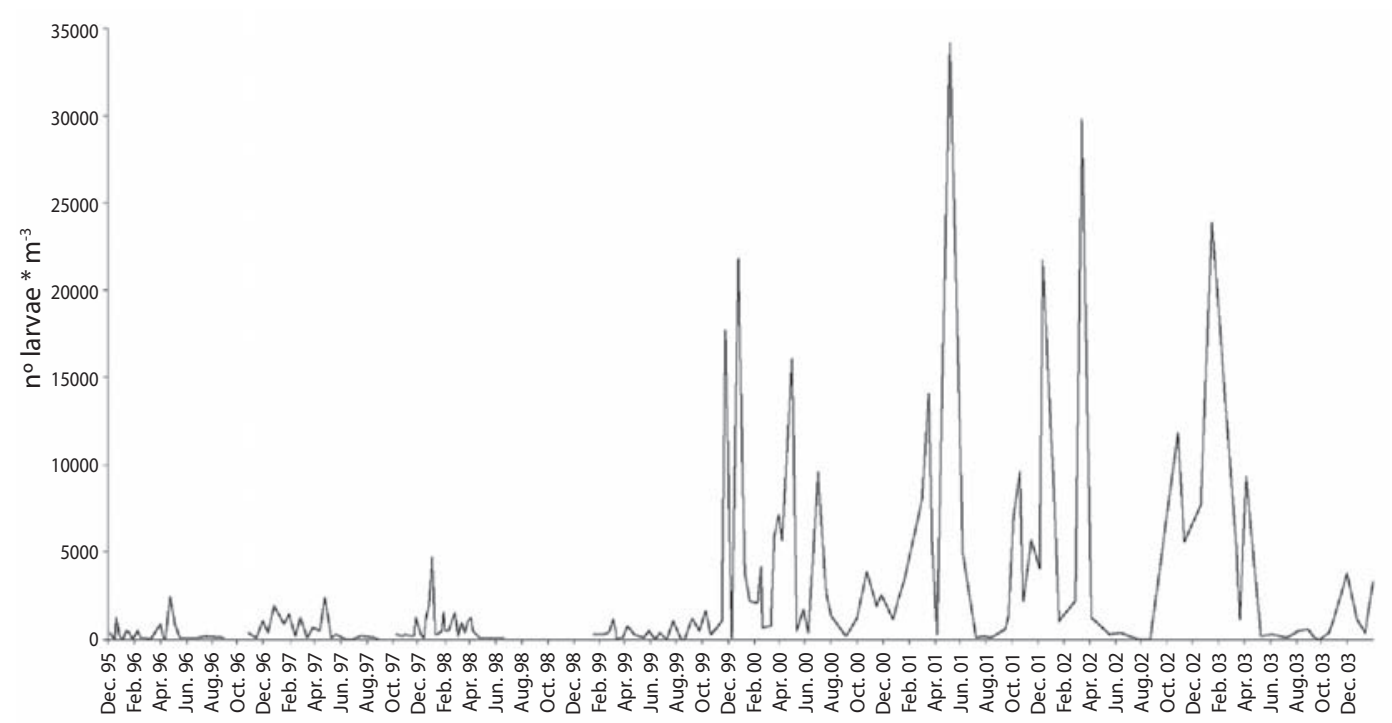

Date

Fig. 2. Total abundances of larvae of A. purpuratus per cubic meter of seawater in the La Rinconada marine reserve between December 1995 and January 2004.

which lasted until April of the following year. The month of May marked the beginning of a decrease in larval abundance, with a tendency to remain stable from June through August. In spite of this cyclical behavior, there were unusual peaks of larval abundance at the end of July and during October 1999, and at the beginning of July 2000; unusual peaks were also observed between May and June 2001. Unfortunately, due to logistical problems which limited our sampling during November and December 1998, observations of periods of high larval abundance during this period were limited to January and April 1999.

Abundance of larval stages: Figure 3 shows the number of larvae found in each sampling both in terms of early veligers $(<170$ $\mu \mathrm{m})$ and umbonate or premetamorphic larvae $(>170 \mu \mathrm{m})$. These results showed the almost continuous presence of advanced larvae throughout all the sampling of this study. Counts of the larger larvae between December 1995 and October 1999 ranged to a maximum of 2323 larvae $\mathrm{m}^{-3}$, and exceeded 1000 in April, November, and
December 1996, February, April, and November 1997, January 1998, and October 1999. In contrast, between November 1999 and April 2003, the maximum value was 25289 larvae $\mathrm{m}^{-3}$, exceeding 5000 in November and December 1999, April and July 2000, March, May, and October 2001, January, March, October, and December 2002, and April 2003.

Bottom-water temperature: bottomwater temperature showed high year-to-year variability in the study area, produced by irregular oceanic phenomena such as El Niño and La Niña. The ENSO event in 1997-98 led to maximum bottom-water temperatures of 21.1 ${ }^{\circ} \mathrm{C}$ and $22.7^{\circ} \mathrm{C}$ in 1997 and 1998 respectively (Fig. 4), and temperatures near $18{ }^{\circ} \mathrm{C}$ during the fall-winter months, which were unusual for this period. On the contrary, temperatures below $16{ }^{\circ} \mathrm{C}$ were frequent during the La Niña event, starting in April 1998. Annual temperature patterns in 1998 and 2003 showed no clear temporal trends, except for the initial winter decrease in temperature and significant increases above $17^{\circ} \mathrm{C}$ restricted to summer. 


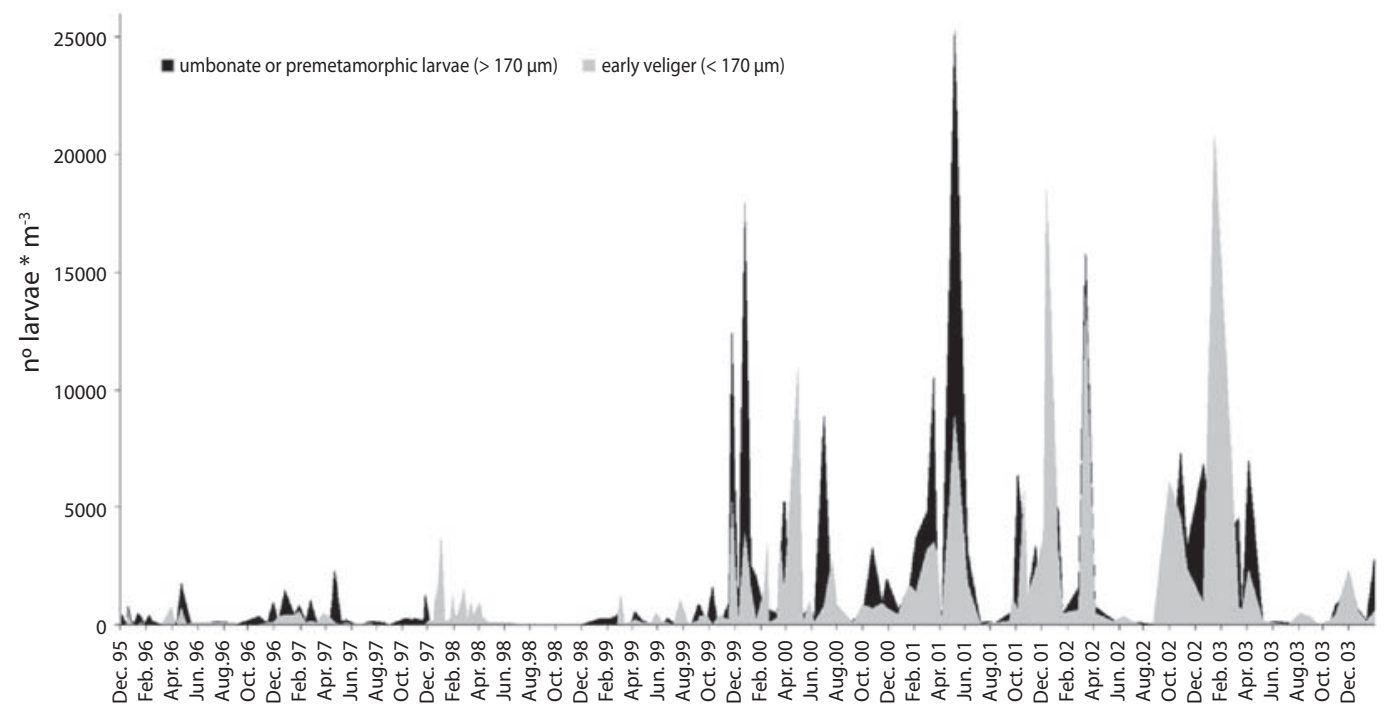

Date

Fig. 3. Abundance and percentages of larvae $\mathrm{m}^{-3}$ of $A$. purpuratus in early $(<170 \mu \mathrm{m})$ and late $(>170 \mu \mathrm{m})$ stages, found in the La Rinconada marine reserve in December 1995 and January 2004.

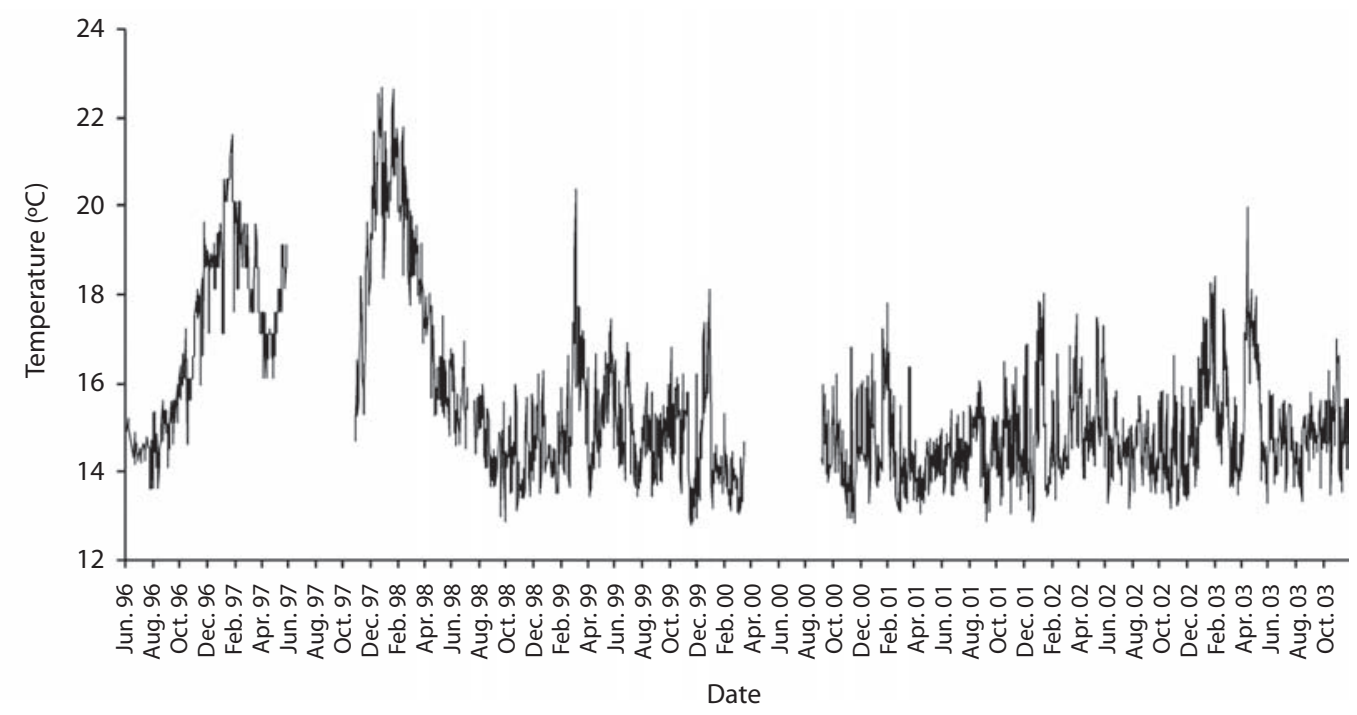

Fig. 4. Average daily water temperature obtained at $16 \mathrm{~m}$ depth at the La Rinconada Marine Reserve, between June 1996 and November 2003.

\section{DISCUSSION}

Knowledge of the reproductive condition of the scallops is a prerequisite for the basic understanding of their recruitment, which can then be profitably applied to the collection of seed organisms which are the basis of mass artificial culture. The gonad index as presented by Mottet (1979) has been shown by a number of researchers to be an inexpensive and rapid 
method of evaluating the reproductive condition of pectinids (Akaboshi and Illanes 1983, Illanes et al. 1985, Wolff 1987, 1988, Avendaño 1993, Avendaño and Le Pennec 1996, 1997, Cantillánez et al. 2005); its results have been corroborated by parallel histological analyses (Avendaño and Le Pennec 1997, Cantillánez 2000, Cantillánez et al. 2005).

Observations on the reproductive strategies of pectinids have demonstrated species specific differences and variations which may depend on the individual populations of the same species (Barber and Blake 1991). For example, Pecten maximus (Linnaeus 1758) in San-Brieuc Bay (Brittany, France) showed gonadal activity beginning in January and February which continued into June and July. Spawnings which gave rise to recruitment generally occurred when the bottom temperature of the water in the bay reached $15-16{ }^{\circ} \mathrm{C}$ (Paulet et al. 1995). In contrast, populations of the same species in the nearby Bay of Brest also began gametogenesis in January/February, but demonstrated spawnings in waves, with their highest amplitudes (usually) from April to September (Paulet et al. 1997). Similar types of variation have been observed among scallop populations around the British Isles (Lubet 1986).

The reproductive strategy of the A. purpuratus population at La Rinconada strongly resembles that of $P$. maximus in the Bay of Brest, having an active reproductive period from September to April, sometimes persisting into May and June as reported by Cantillánez et al. (2005). This strategy of "dropwise" spawnings, followed by rapid maturation of sex cells, allows for semi-continuous production of larvae, in a way that at least some of these will encounter favorable environmental conditions over time which favor their subsequent development.

The synchrony shown by the results obtained with the coefficient of variability in the GI for the reproductive events in this population confirmed the contention of Cantillánez et al. (2005). These results also show a general tendency toward asynchrony of the individuals in the bed in March and April, also noted by
Avendaño and Le Pennec (1996, 1997). The period of active gamete production in which a maximum intensity is reached during the months of April and May in P. maximus in the Bay of Brest (Paulet et al. 1997), is a highly synchronized process, also occurring just prior to the major spawnings of $A$. purpuratus as shown in the present study.

As a result of reproductive activity shown by the $A$. purpuratus population, the larval samplings carried out from December 1995 to January 2004 showed the presence of larvae throughout the year with important declines in between the end of May and beginning of August, which can be compared a priori, with low values observed in the GI during this period. Most of the larvae collected were present between November and April, corresponding with the highest GI values. The increase in this index, occurring between the end of December 1999 and February 2003, correlated with unusually high rises in the number of larvae during this period, showing an unusual peak of 9600 larvae $\mathrm{m}^{-3}$ in July 2000 as a result of the June spawning toward the end of the La Niña period (Cantillánez 2000). These relations were flexible, however, as observed with some species, including P. maximus (Paulet et al. 1997), and Ruditapes phillippinarum (Adams and Reeve 1850) (Calvez 2002), where the highest GI values were not strictly associated with the highest numbers of larvae of these species in the plankton, and where low GI values were not necessarily linked to absence of reproduction. Thus with P. maximus in the Bay of Brest, it is possible to find larvae in winter (Paugam et al. 2003), in a period when the GI is low.

Few studies have been carried out on the presence in the plankton of pectinid larvae, especially for species including $A$. purpuratus, although the presence of these larvae is a good indicator of population abundance as observed early in the past century (Hjort 1914). This finding has been revisited by a number of authors employing deterministic models which explain the regulation of recruitment (Cushing 1982, Lewin 1986, Rothshild 1986, Roughgarden et al. 1988, Sinclair 1988, 
Underwood y Fairweather 1989, Doherty and Fowler 1994). Dames and Moore (1994) suggested that lack of such study has been due to the high cost and effort required of this type of research, where the potential benefits are of a long-term nature. Nevertheless, recent studies on species such as Placopecten magellanicus (Gmelin 1791), and P. maximus, have allowed some understanding of larval dynamics (Sinclair et al. 1985, Thouzeau et al. 1991, Salaün 1994).

In general terms, the lack of knowledge concerning larval phases of bivalves has been due to difficulty in identifying them to species as well as locating them within oceanic water masses. Apart from larval ostreidae, whose prodissoconch morphology makes them recognizable even in a stereoscopic microscope, most bivalve larvae are identifiable only by the morphology of the hinge, through the use of scanning electron microscopy (Le Pennec 1978). A new method for the specific identification of bivalve larvae is the use of immunology (Paugam et al. 2000), which may allow discarding the use of SEM, although requiring employment of immunological techniques using materials produced in shellfish hatcheries. This method has been successfully applied in France for identifying larvae of $R$. philippinarum in the Gulf of Morbihan (Calvez 2002), and those of $P$. maximus in the Bay of Brest (Paugam et al. 2003).

Larvae of the pectinids show remarkable similarity between species. In the Bay of San-Brieuc, France, Salaün (1994) was able to distinguish $P$. maximus larvae from those of Aequipecten opercularis (Linnaeus 1758) and the mussel Mytilus edulis (Linnaeus 1758), abundantly present in plankton samples, by noting the purple-violet coloration uniquely present in the provinculum of $P$. maximus larvae when observed in a binocular microscope. This character, also observable in the prodissoconch of $A$. purpuratus, allows this species to be easily distinguished from other bivalve veligers such as those of Semimytilus algosus (Gould 1850) present in the La Rinconada reserve, a larva which otherwise is very similar to that of the scallop.

The recognition of $A$. purpuratus larvae allowed determinations of their variability in the water column throughout the present study, where densities of up to 34175 larvae $\mathrm{m}^{-3}$ were observed in May 2001. This result was among the highest ever observed in Chilean waters, compared with previous literature values of 40 to 450 larvae $\mathrm{m}^{-3}$ in Tongoy Bay (Akaboshi and Illanes 1983), reaching $1200 \mathrm{~m}^{-3}$ during El Niño periods (Illanes et al. 1985), and in Mejillones Bay, near Antofagasta, with 30 to 200 larvae $\mathrm{m}^{-3}$ (Navarro et al. 1991), reaching a maximum of $4000 \mathrm{~m}^{-3}$ during an El Niño (Hojas 1982). For comparison, larval densities of $P$. maximus in the Bay of Brest are typically 200 larvae $\mathrm{m}^{-3}$ unusually reaching values of 600 larvae $\mathrm{m}^{3}$ (Paugam et al. 2003). The extraordinarily high density of $A$. purpuratus veligers, and their ease of identification, allowed for an uncomplicated study of the pelagic phase of this scallop resulting from local spawnings.

Water samples from La Rinconada, contained A. purpuratus larvae which could be readily separated into two categories, including those from 110 to $170 \mu \mathrm{m}$ (small), and those from 171 to $244 \mu \mathrm{m}$ (large). The former represented early veliger larvae and the latter mature umbonate larvae with a definitive provinculum (Le Pennec 1978) nearing metamorphosis. Dates of spawning events could be hindcasted by knowing the larval sizes present in the water column, water temperature, and food availability to the larvae (Cantillánez 2000, Avendaño et al. 2004, 2006). The almost constant presence of larvae at, or nearing competence $(>170 \mu \mathrm{m})$, showed the capacity for the La Rinconada area, for retention of these larvae and allowing their settlement on natural substrates or, in artificial collectors (Cantillánez 2000, Avendaño and Cantillánez 2005, Avendaño et al. 2006). At the end of the pelagic phase the pediveliger settles preferentially on Rhodymenia sp. and passes metamorphosis (Navarro et al. 1991, Avendaño 1993).

An explanation for the increases in GI and numbers of larvae in 1999 and the beginning 
of 2003, when compared with those occurring between 1995 and October 1999 resides in the literature published on this bed. Data shown in Table 1 indicate that these variations followed an increase in the size structure and the numbers of reproducing individuals found in the A. purpuratus population during those years. Individuals over the legal size limit, established in Chile as $90 \mathrm{~mm}$ in anteroposterior length (and according to Avendaño et al. 2001, those that contribute the largest numbers of gametes), became strongly reduced between 1995 and 1998, due to illegal (clandestine) harvesting in the bed during this period, which selectively affected individuals of the larger size classes (Avendaño and Cantillánez 1996, 1997). The creation of the marine reserve in 1997 and establishment of a team of watchmen beginning in 1999, permitted an increase in the larger size classes of scallops between the end of 1999 and 2002, again declining during 2003 (Avendaño et al. 2004, Avendaño and Cantillánez 2005) (Table 1). This more recent decline was clearly reflected by the decrease in the numbers of larvae beginning in June 2003. Data presented by Avendaño et al. (2004), through estimation of the total biomass of spawning scallops for 1999, 2000, and 2001 suggested that the sizes which most contributed to larval production during these three years were the 82.5; 92.7 and $92.4 \mathrm{~mm}$ scallops, respectively.

The results also show, considering the population size structure shown by A. purpuratus in La Rinconada (Table 1), that larval abundance could vary in the presence of large-scale oceanographic phenomena such as El Niño. This accompanied a strong thermal anomaly that from March to December 1997 caused an increase in water temperature of $5{ }^{\circ} \mathrm{C}$, which had a positive effect on the reproduction and larval densities in this period, at a time in which the bed was populated mainly by juvenile individuals. These abundances were not related to those obtained between November 1999 and April 2003, although during this period, there was an entry of cold water into the area caused by a La Niña phenomenon which disturbed normal reproduction and recruitment (Wolff 1988, Cantillánez 2000).

The present research on A. purpuratus, considered to be a subtropical relict species by Wolff (1987), revealed several aspects of its reproductive cycle and larval phase. Future research should be oriented toward optimization of artificial capture of seed of this species in order to promote its culture and management.

TABLE 1

Size structure of the population of Argopecten purpuratus from the La Rinconada during eight years of observations, showing numbers of legal sized scallops present

\begin{tabular}{ccccc}
\multicolumn{2}{c}{ Range of Total Lengths } & Mean & SD & $\mathrm{N}^{\mathrm{o}}$ Legal Size $^{\mathrm{a}}$ \\
Date & $\mathrm{mm}$ & $\mathrm{mm}$ & & \\
$10 / 1993$ & $10.0-114.9$ & 51.8 & 21.52 & $1.9^{*} 10^{5}$ \\
$5 / 1996$ & $5.0-110.0$ & 50.2 & 19.96 & $5.3^{*} 10^{4}$ \\
$5 / 1997$ & $5.0-100.0$ & 61.5 & 27.61 & $1.3^{*} 10^{5}$ \\
$3 / 1999$ & $6.3-125.0$ & 65.5 & 25.99 & $1.4^{*} 10^{6}$ \\
$3 / 2000$ & $5.7-132.5$ & 57.8 & 37.01 & $2.3^{*} 10^{6}$ \\
$3 / 2001$ & $10.2-137.2$ & 75.8 & 19.82 & $2.6^{*} 10^{6}$ \\
$5 / 2002$ & $10.0-135.2$ & 62.1 & 24.47 & $9.3 * 10^{5}$ \\
$5 / 2003$ & $10.3-123.0$ & 51.7 & 19.32 & $3.7^{*} 10^{5}$
\end{tabular}

$\mathrm{SD}=$ standard deviation $\left({ }^{\mathrm{a}}\right)=90 \mathrm{~mm}$ or more.

(data from Cantillánez and Avendaño 1994, Avendaño and Cantillánez 1996, 1997, 2005, Avendaño et al. 2004). 
Nevertheless, the present results allow us to conclude that production of larval scallops in numbers sufficient to sustain optimal catches of seed of this species depends primarily on the densities of parent stock in the bed, as concluded for P. maximus by Buestel and Dao (1979).

\section{ACKNOWLEDGMENTS}

The present study was carried out within the framework of the FNDR project, Code BIP N ${ }^{\circ}$ 20127869-0 and the ECOS-CONICYT C98B02 program. The authors thank Louis Disalvo for translation, commentary and helpful suggestions for the MS.

\section{RESUMEN}

Entre 1995 y 2004 se determinó, con el índice gonadosomático, el ciclo reproductivo de Argopecten purpuratus en La Rinconada, Antofagasta, Chile. Paralelamente se realizaron muestreos larvales mediante arrastres verticales de plancton. La reproducción, en años normales y fríos (La Niña, 1998-2000), ocurre todo el año, con un período más intenso entre septiembre y abril, declinando en junio y agosto. En contraste, esta actividad no declina en condiciones de "El Niño" 1997-1998. En esta población los eventos reproductivos son sincrónicos, con un período altamente asincrónico entre marzo y mayo, al culminar los desoves más intensos. Esta actividad reproductiva, genera la presencia continua de larvas en el área. No hay relación entre intensidad de puestas y número de larvas, sin embargo, los períodos de mayor abundancia están directamente relacionados con períodos de mayor actividad reproductiva. Los incrementos importantes en el número de larvas entre fines de 1999 y comienzos del 2003 se asocian con un mayor número de reproductores sobre $90 \mathrm{~mm}$ de longitud. Esto indica la importancia de mantener un stock adecuado de este grupo demográfico, si se espera implementar programas de captación larval de esta especie en la reserva.

Palabras clave: Argopecten purpuratus, ciclo reproductivo, ciclo larval, bahía de Antofagasta, Chile.

\section{REFERENCES}

Akaboshi, S. \& J.E. Illanes. 1983. Estudio experimental sobre la captación, pre-cultivo y cultivo, en ambiente natural de Chlamys (Argopecten) purpurata, Lamarck 1819, en Bahía Tongoy, IV Región,
Coquimbo. Symposium Internacional de Acuacultura. Coquimbo-Chile-Septiembre 1983.

Avendaño, M. \& M. Cantillánez. 1992. Colecta artificial de semilla de A. purpuratus (Lamarck, 1819) en la Bahía de Mejillones, Chile. II. Observaciones sobre niveles óptimos de captación. Estud. Oceanol. 11: 39-43.

Avendaño, M. 1993. Données sur la biologie de Argopecten purpuratus (Lamarck, 1819), Mollusque Bivalve du Chili. Ph. D. Thesis, Université de Bretagne Occ. Brest, France.

Avendaño, M. \& M. Cantillánez. 1996. Efectos de la pesca clandestina, sobre Argopecten purpuratus (Lamarck, 1819), en el banco La Rinconada, II Región. Cienc. Tec. Mar. 19: 57-65.

Avendaño, M. \& M. Le Pennec. 1996. Contribución al conocimiento reproductivo de Argopecten purpuratus (Lamarck, 1819), en dos poblaciones de la II RegiónChile. Estud. Oceanol. 15: 1-10

Avendaño, M. \& M. Le Pennec. 1997. Intraspecific variation in gametogenesis in two populations of the Chilean mollusc bivalve, Argopecten purpuratus (Lamarck). Aquacul. Res. 28: 175-183.

Avendaño, M. \& M. Cantillánez. 1997. Necesidad de crear una reserva marina en el banco de ostiones de La Rinconada-II Región. Estud. Oceanol. 16: 109-113.

Avendaño, M. \& M. Cantillánez. 1997b. Análisis para la recuperación del banco de ostiones de La Rinconada, Antofagasta-II Región. Informe Final Proyecto FNDR Cód. BIP N 20100479-0, Antofagasta, Chile.

Avendaño, M., M. Le Pennec \& M. Cantillánez. 2001. Anormalidades en larvas de Argopecten purpuratus (Lamarck, 1819) (Mollusca: Pectinidae), una causal de los problemas en la producción artificial de semi1la. Estud. Oceanol. 20: 32-42.

Avendaño, M., M. Cantillánez, L. Rodríguez, O. Zúñiga, R. Escribano \& M. Oliva. 2004. Conservación y protección Reserva Marina La Rinconada AntofagastaChile. Informe Final Proyecto FNDR Cód. BIP N ${ }^{\circ}$ 20127869-0, Antofagasta, Chile.

Avendaño, M. \& M. Cantillánez. 2005. Growth and demographic structure of Argopecten purpuratus (Lamarck, 1819), in the La Rinconada Marine Reserve, Antofagasta, Chile. Cienc. Mar. 31: 491-503.

Avendaño, M., M. Cantillánez \& J. Peña. 2006. Effect of immersion time of culthch on spatfall of the scallop Argopecten purpuratus (Lamarck 1819) in the 
Marine Reserve at La Rinconada, Antofagasta, Chile. Aquacul. Int. 14: 267-283.

Barber, B. \& N. Blake. 1991. Reproductive Physiology, p. 377-428. In S.E. Shumway (ed.). Scallops: Biology, Ecology and Aquaculture. Elsevier, New York, USA.

Buestel, D. \& J.C. Dao. 1979. Aquaculture extensive de la coquille Saint-Jacques: Résultats d'un semis expérimental. Pêche Maritime: 1-7.

Calvez, I. 2002. Approche de la variabilité spatiale des stades larvaires et post-larvaires d'une population de palourdes japonaises, Ruditapes philippinarum. $\mathrm{Ph}$. D. Thesis, Université de Bretagne Occ. Brest, France.

Cantillánez, M. \& M. Avendaño. 1994. Situación actual del recurso Ostión del Norte (Argopecten purpuratus, Lamarck, 1819), en el banco de La Rinconada, II Región-Chile. Infor. Final. Proy. F.N.D.R. II Región, Antofagasta, Chile. 58 p.

Cantillánez, M. 2000. Reproduction, vie larvaire et prérecrutement du Pectinidae Argopecten purpuratus (Lamarck, 1819) dans la baie d'Antofagasta (Chili). $\mathrm{Ph}$. D. Thesis, Université de Bretagne Occ. Brest, France.

Cantillánez, M., G. Thouzeau \& M. Avendaño. 2001. Reproductive cycle in Argopecten purpuratus during El Niño and la Niña conditions: a case study in the Rinconada Bay (Chile). 13th International Pectinid Workshop, 18-24 April 2001, Coquimbo, Chile

Cantillánez, M., M. Avendaño, G. Thouzeau \& M. Le Pennec. 2005. Reproductive cycle of Argopecten purpuratus (Bivalvia: Pectinidae) in la Rinconada marine reserve, (Antofagasta, Chile): response to environmental effects of El Niño and La Niña. Aquaculture. 246:181-195

Cushing, D.H. 1982. Climate and fisheries. Academic, London, England.

Dames \& Moore. 1994. Evaluación directa del Ostión del Norte de la III y IV Regiones Informe Tecnico FIP. FIP-IT 94-14, Valparaiso, Chile.

Doherty, P. \& T. Fowler. 1994. An empirical test of recruitment limitation in a coral reef fish. Science 263: 935-939.

Escribano, R., L. Rodríguez \& C. Irribarren. 1995. Temporal variability of sea temperature in Bay of Antofagasta, northern Chile (1991-1995). Estud. Oceanol. 14: 39-47.

Guillen, O. 1983. Condiciones oceanográficas y sus fluctuaciones en el Pacífico Sur-oriental, p. 607-658. In G.D. Sharp \& J. Csirke (eds). Actas de la consulta de expertos para examinar cambios en la abundancia y composición por especies de recursos de peces neríticos, San José, Costa Rica, 1983. FAO inf. Pesca 291-3, San José, Costa Rica.

Hojas, F. 1982. Antecedentes sobre el cultivo del Ostión del Norte, en Antofagasta, Chile. Chile Pesquero, marzo 1982, s.p.

Hjort, J. 1914. Fluctuations in the great fisheries of Northern Europe. Rapp. Cons. Expl. Mer. 20: 1-228.

Illanes, J., S. Akaboshi \& E. Uribe. 1985. Efectos de la temperatura en la reproducción del ostión del norte Chlamys (Argopecten) purpurata, en la Bahía de Tongoy, durante el fenómeno "El Niño 1982-83". Invest. Pesq. (Chile) 32: 167-173.

Le Pennec, M. 1978. Génèse de la coquille larvaire et postlarvaire chez divers Bivalves marins. Ph. D. Thesis, Université de Bretagne Occ. Brest, France.

Lewin, R. 1986. Supply-side ecology. Science 234: 25-27.

Lubet, P. 1986. The reproductive strategies of marine bivalve mollusks. Adv. Invert. Reprod. 4: 401-408.

Marín, V., L. Rodríguez, L. Vallejo, J. Fuenteseca \& E. Oyarce. 1993. Efectos de la surgencia costera sobre la productividad primaria primaveral de Bahía Mejillones del Sur (Antofagasta, Chile). Rev. Chil. Hist. Nat. 66: 479-491.

Mottet, M.G. 1979. A review of the fishery biology of scallops. Tech. Rep. Dept. Fish., Washington, USA.

Navarro, R., L. Sturla, L. Cordero \& M. Avendaño. 1991. Chile, p. 1001-1015. In S.E. Shumway (ed.). Scallops: Biology, Ecology and Aquaculture. Elsevier, New York, USA.

Paugam, A., M. Le Pennec \& G. André-Fontaine. 2000. Inmunological recognition of marine bivalve larvae from plankton. J. Shellfish Res. 19: 325-331.

Paugam, A., M. Le Pennec, A. Marhic \& G. AndréFontaine. 2003. Inmunological in situ determination of Pecten maximus larvae and their temporal distribution. J. Mar. Biol Assoc. U.K. 83: 1083-1093. 
Paulet, Y.M., F. Bekhadra, N. Devauchelle, A. Donval \& G. Dorange. 1995. Cycles saisonniers, reproduction et qualité des ovocytes chez Pecten maximus en rade de Brest. Actes de colloques, 3ièmes Rencontres Scientifiques Internationnales, Programme Rade de Brest. 2: 15-18.

Paulet, Y.M., F. Bekhadra, N. Devauchelle, A. Donval \& G. Dorange. 1997. Cycles Saisonniers, Reproduction et Qualité des Ovocytes chez Pecten maximus en Rade de Brest. Ann. Inst. Océanogr. Paris 73: 101-112.

Rodríguez, L., V. Marín, M. Farias \& E. Oyarce. 1991. Identification of an upwelling zone by remote sensing and in situ measurements. Mejillones del Sur Bay (Antofagasta-Chile). Sci. Mar. 55: 467-473.

Rothschild, B.J. 1986. Dynamics of marine fish populations. Harvard, Massachussetts, USA

Roughgarden, J., S. Gaines \& H. Possingham. 1988. Recruitment dynamics in complex life cycles. Science 24: 1461-1466.

Salaün, M. 1994. La larve de Pecten maximus, genese et nutrition. Ph. D. Thesis, Université de Bretagne Occ. Brest, France.
Sinclair, M., R. Mohn, G. Robert \& D. Roddick. 1985. Considerations for the effective management of Atlantic scallops. Can. Tech. Rep. Fish. Aquat. Sci. 1382: $1-113$

Sinclair, M. 1988. Marine populations. An essay on population regulation and speciation. Univ. Washington, Seattle, USA.

Thouzeau, G., G. Robert \& S. Smith. 1991. Spatial variability in distribution and growth of juvenile and adult sea scallops Placopecten magellanicus (Gmelin) on eastern Georges Bank. Mar. Ecol. Prog. Ser. 74: 205-218

Underwood, A. \& P. Fairweather. 1989. Supply-side ecology and benthic marine assemblages. Trends Ecol. Evol. 4: 16-20

Wolff, M. 1987. Population Dynamics of the Peruvian scallop Argopecten purpuratus during the El Niño Phenomenon of 1983. Can. J. Fish. Aquat. Sci. 44: 1684-1691.

Wolff, M. 1988. Spawning and recruitment in the Peruvian scallop Argopecten purpuratus. Mar. Ecol. Prog. Ser. 42: 213-217. 